\title{
Daily rhythm of corticosterone in laying hens and the influence of egg laying
}

\author{
G. Beuving and G. M. A. Vonder \\ Spelderholt State Institute for Poultry Research, Beekbergen, The Netherlands
}

The modern way of intensive rearing of poultry has provoked much criticism and has elicited an increased interest in factors concerning the welfare, especially stress, of the animals. Corticosterone plays an important role in the stress syndrome. It is the main corticosteroid in avian plasma, but little is known about its normal level in the blood because the methods for estimating this hormone were not accurate enough.

Until recently, corticosterone was determined with fiuorometric methods, but variable and high values have been found (Frankel, 1970). Purification of plasma samples gave much lower hormone values; e.g. Boissin \& Assenmacher (1968) demonstrated a daily rhythm of corticosterone concentration in plasma of adult male quails with values between 10 and $50 \mathrm{ng} / \mathrm{ml}$ plasma after purification by thin-layer chromatography. Culbert \& Wells (1975) applied column chromatography and found values in the range of $7-20 \mathrm{ng} / \mathrm{ml}$ plasma of laying hens. Brown (1967) also applied column chromatography and found values of $10 \mathrm{ng} / \mathrm{ml}$ plasma in 4-week-old chickens. The application of competitive protein-binding methods resulted in further lowering of the reported hormone level. In 39-day-old chickens Buckland \& Blagrave (1973) found values of $5 \mathrm{ng} / \mathrm{ml}$ plasma. Still lower values (2.2 ng/ml) were shown by Weiss \& Brand (1974) in broilers. In laying hens the highest value was of $2.7 \mathrm{ng} / \mathrm{ml}$, but the hormone was not detectable in all birds. Effects of handling, or the immobilization stress, inevitable when blood samples are taken, were not excluded in any of these studies.

We therefore tried to overcome this problem in a study of the daily rhythm of corticosterone concentrations in laying hens.

\section{Methods}

The birds used for establishing the daily rhythm were White Leghorn hens from an experimental line of the Institute. The birds used for the other experiments were also White Leghorns (Shaver 288). All birds (25-30 weeks old) were housed individually in cages during the experiments.

To prevent the effects of handling and immobilization, cannulation was performed at least $38 \mathrm{~h}$ before the first blood sample was taken (Beuving, 1976). Polyethylene tubing (PP 30) was inserted into the wing artery under local anaesthesia and was led outside the cage. Heparin (about 1000 units) was given daily through the cannula to prevent clots forming in the cannula. The presence of the cannula and the withdrawal of blood $(3 \mathrm{ml})$ did not appear to disturb the birds. The blood samples were centrifuged to remove blood cells.

Dichloromethane, petroleum ether, toluene and methanol, all of analytical grade, were purchased from Merck, Darmstadt, and redistilled before use. $\left[1,2,6,7-{ }^{3} \mathrm{H}\right]$ Corticosterone and $\left[1,2,6,7-{ }^{3} \mathrm{H}\right]-$ progesterone (sp. act. $102 \mathrm{Ci} / \mathrm{mmol}$ and $94 \mathrm{Ci} / \mathrm{mmol}$, respectively) were obtained from the Radiochemical Centre, Amersham, U.K., diluted in 0.01 M-phosphate buffer ( $\mathrm{pH} 7.3$ ) and stored in the deep freeze. Florisil (Koch-Light Laboratories, Colnbrook, U.K.; 60-100 mesh) was tested for binding capacity before use: more than $90 \%$ of the radioactivity was bound in the range of 2-10 ng corticosterone. Fine particles were removed by washing. Florisil was dried at $100^{\circ} \mathrm{C}$.

Radioactive corticosterone $\left(1.5 \times 10^{4} \mathrm{~d} / \mathrm{min}\right)$ was added to $1.0 \mathrm{ml}$ plasma for determination of the recovery. To remove progesterone the solution was extracted with $2 \times 10 \mathrm{ml}$ petroleum ether in stoppered tubes on a Vortex during $45 \mathrm{sec}$. Corticosterone was extracted with $2 \times 8 \mathrm{ml}$ dichloromethane by shaking for $15 \mathrm{sec}$. After drying with air at $40^{\circ} \mathrm{C}$, the residue was redissolved in $3.0 \mathrm{ml}$ methanol, centrifuged, and evaporated again. The residue was dissolved in $0.1 \mathrm{ml}$ toluene-methanol $(9: 1 \mathrm{v} / \mathrm{v})$, applied to a Sephadex LH-20 column $(5.5 \times 0.6 \mathrm{~cm})$ and eluted with toluene-methanol 
$(9: 1 \mathrm{v} / \mathrm{v})$. The first $1.3 \mathrm{ml}$ of the eluate was discarded and the next $1.5 \mathrm{ml}$ were used. After evaporation, the residue was dissolved in $0.2 \mathrm{ml} 0.01 \mathrm{M}$-sodium phosphate buffer, $\mathrm{pH} 7 \cdot 3$, by shaking for $15 \mathrm{~min}$ at $40^{\circ} \mathrm{C}$ in a water bath, and $50 \mu \mathrm{l}$ were counted in a Nuclear Chicago scintillation counter (Unilux II). Corticosteroid binding globulin solution $(100 \mu \mathrm{l})$ with radioactive corticosterone $\left(4 \times 10^{4} \mathrm{~d} / \mathrm{min}\right)$ was added to $100 \mu \mathrm{l}$ of the solution and used for the competitive protein-binding assay as described for cortisol by de Jong \& van der Molen (1972). Free corticosterone was bound with Florisil. The amount of corticosterone was read from a standard curve with values in the range of 0-3 ng corticosterone. Plasma of pregnant women (third trimester) was used as the source of the CBG solution; the plasma was shaken for $20 \mathrm{~min}$ with charcoal, centrifuged $(20 \mathrm{~min}$ at $15,000 \mathrm{~g}$ ), filtered to remove fine charcoal particles, diluted with glycerol $(1: 1)$ and stored at $-15^{\circ} \mathrm{C}$.

\section{Results and discussion}

The competitive protein-binding method of de Jong \& van der Molen (1972) was tested for corticosterone measurement in plasma of laying hens by varying the plasma volume and by determination of the recovery of internal standards. Ethanol and dichloromethane were examined as extraction solvent. Dichloromethane was preferred because fewer impurities were present after evaporation. The efficiencies of a first and a second extraction were $63 \%$ and $12 \%$, respectively. Because dichloromethane extraction of plasma alone did not yield sufficiently pure samples, a purification of the assay samples by column chromatography (Sephadex LH-20) was applied. This had the further advantage of giving low blank values (Murphy, 1971). After chromatography, a clear solution was obtained and used in the assay. The average recovery of column chromatography for 5 different chicken plasma samples was $67 \%$; the recovery from a pure corticosterone solution was $65 \%$. The total recovery after extraction and purification in the experiments was about $50 \%$.

Progesterone may be present in considerable amounts in the plasma of laying hens with peak values of $5 \mathrm{ng} / \mathrm{ml}$ at $4-7 \mathrm{~h}$ before ovulation and basal levels $<2 \mathrm{ng} / \mathrm{ml}$ (Furr, Bonney, England \& Cunningham, 1973). Aldosterone has a very low affinity for human CBG (Murphy, 1967). No other progestins or corticosteroids have been reported to be present in the plasma of laying hens (Kappauf $\&$ Van Tienhoven, 1972; Furr, 1973) and progesterone was therefore removed with $81 \%$ efficiency by washing with petroleum ether. Less than $1 \%$ corticosterone was removed by this treatment.

The accuracy of the method is demonstrated in Table 1 . The intra-assay error was $0.70 \mathrm{ng}(n=27)$ in the range of 7-11 $\mathrm{ng}$ corticosterone $/ \mathrm{ml}$ plasma and $0.40 \mathrm{ng}$ at $2 \mathrm{ng}$ corticosterone $/ \mathrm{ml}$ plasma $(n=16)$. The inter-assay error, determined from duplicate assays, was $0.41 \mathrm{ng}$ in the range of 2-5 $\mathrm{ng} / \mathrm{ml}$ plasma (20 duplicates) and $0.70 \mathrm{ng}$ in the range of $5-10 \mathrm{ng} / \mathrm{ml}$ plasma (20 duplicates). The least detectable dose was $0 \cdot 15 \mathrm{ng}$ corticosterone at the CPB stage, i.e. twice the standard deviation of 15 duplicate blank values.

Table 1. The accuracy of the corticosterone determinations in plasma of laying hens when (a) the plasma volume and (b) the amount of corticosterone added was varied

\begin{tabular}{|c|c|c|c|c|c|}
\hline & \multirow{2}{*}{$\begin{array}{l}\text { Plasma vol. } \\
\text { (ml) }\end{array}$} & \multicolumn{4}{|c|}{$\begin{array}{l}\text { Endogenous corticosterone } \\
\text { (ng/ml plasma) }\end{array}$} \\
\hline & & I & II & III & IV \\
\hline $\begin{array}{l}\text { (a) Plasma of } 4 \text { different laying hens, } \\
\text { obtained by heart puncture }\end{array}$ & $\begin{array}{l}0.5 \\
1.0 \\
1.5\end{array}$ & $\begin{array}{l}6 \cdot 3 \\
5 \cdot 6 \\
6 \cdot 4\end{array}$ & $\begin{array}{l}6 \cdot 5 \\
6 \cdot 4 \\
6 \cdot 1\end{array}$ & $\begin{array}{r}10.1 \\
9.0 \\
8.6\end{array}$ & $\begin{array}{l}8 \cdot 2 \\
7 \cdot 0 \\
7 \cdot 2\end{array}$ \\
\hline
\end{tabular}

(b)

Endogenous plasma corticosterone $(\mathrm{ng} / \mathrm{ml})$ in three different plasma samples
Conc. plasma corticosterone $(\mathrm{ng} / \mathrm{ml})$ with added corticosterone

\begin{tabular}{ccc}
\hline$+5 \mathrm{ng}$ & $+10 \mathrm{ng}$ & $+15 \mathrm{ng}$ \\
\hline $5.7(85 \%)$ & $12.2(104 \%)$ & $17.4(104 \%)$ \\
$7.4(96 \%)$ & $12.5(98 \%)$ & $19.7(11 \%)$ \\
$6.6(93 \%)$ & $11.8(98 \%)$ & $17.3(101 \%)$ \\
\hline
\end{tabular}




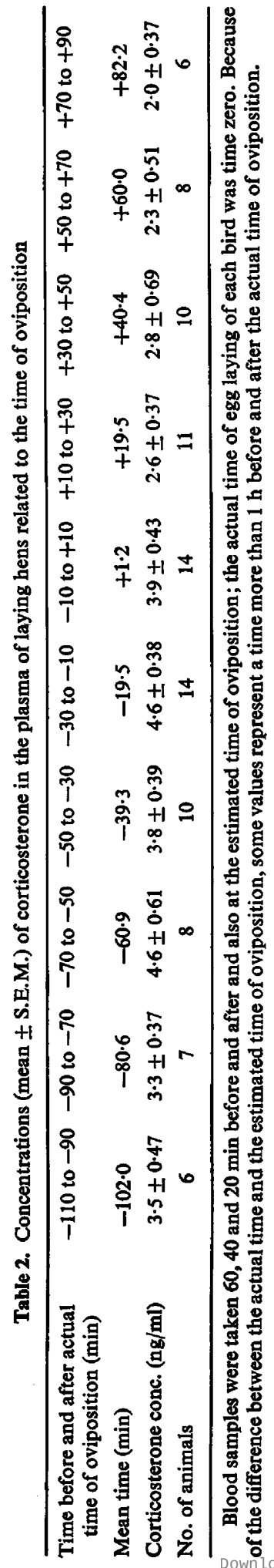


Examination of the levels of plasma corticosterone in laying hens every $3 \mathrm{~h}$ for $24 \mathrm{~h}$ showed that the individual variation was considerable but that there was a clear daily rhythm (Text-fig. 1). A maximum at the end of the dark period and a minimum at the beginning of the night were found $(2.3$ and $0.5 \mathrm{ng} / \mathrm{ml}$ plasma, respectively). Although the maximum occurred at the end of the dark or at the beginning of the light period, the rise of corticosterone levels clearly began before photostimulation could have had any influence.

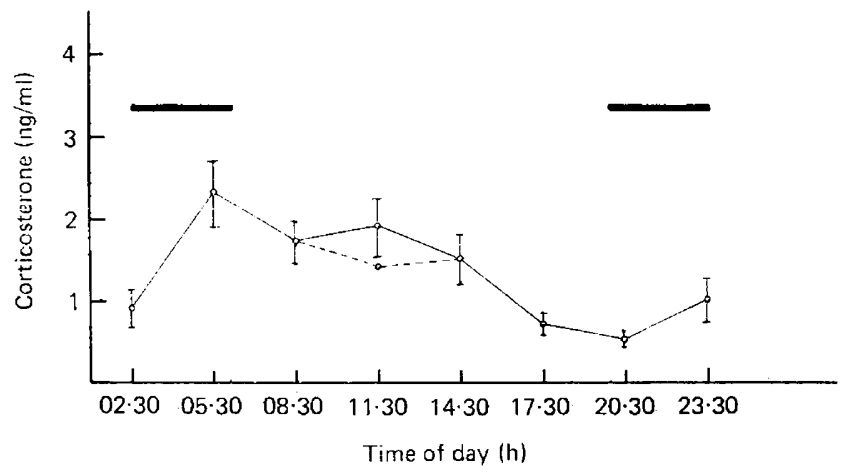

Text-fig. 1. Daily variation in the mean ( \pm S.E.M.) corticosterone content in the plasma of 10 laying hens. The dark period from 20.00 to $06.00 \mathrm{~h}$ is shown by the horizontal bar. Three eggs were laid when blood samples were taken at $11.30 \mathrm{~h}$; the dashed line (--) represents the value when the hormone concentrations in these 3 birds are omitted.

The relationship between hormone concentration and time can be described by a regression equation $y=-0.604+0.794 x-0.0693 x^{2}+0.00163 x^{3}$ (correlation coefficient $0.92 ; P \approx 0.015$; $n=8$ ). The results of this experiment agree fairly well with the diurnal rhythm (i.e. peak levels during the night and a minimum at the end of the day) of corticosterone levels in male quails in natural lighting conditions and in various artificial photoperiods (Boissin \& Assenmacher, 1968, 1970). Joseph \& Meyer (1973) found a similar pattern in pigeons (mixed sexes).

The influence of egg laying was further examined, also with cannulated birds. Blood samples were taken at 20-min intervals for $2 \mathrm{~h}$, beginning $1 \mathrm{~h}$ before the estimated time of oviposition; the values obtained (Table 2) were not corrected for the daily rhythm or for haemodilution caused by blood sampling. (The laying hens used for these experiments had an average weight of $1.5 \mathrm{~kg}$ and a blood volume of about $100 \mathrm{ml}$ (Sturkie, 1976); withdrawal of one blood sample therefore caused a haemodilution of $3 \%$.) The hormone concentration was already elevated $100 \mathrm{~min}$ before the time of egg laying. The relationship between hormone concentration and time relative to oviposition can be described by a regression equation, $y=3.71-0.013 x-0.00015 x^{2}$ (correlation coefficient $0.85 ; P<0.05 ; n=10$ ). The maximum of $4.0 \mathrm{ng}$ corticosterone/ml plasma was found $44 \mathrm{~min}$ before egg laying, but hormone levels had returned to normal values by $1 \mathrm{~h}$ after egg laying.

The increase in corticosterone content is not unexpected because the birds cannot perform their normal laying behaviour in cages and are usually in a state of agitation before an egg is laid. The duration of this period varies and is about $1 \mathrm{~h}$ (Martin, 1975). The increase of corticosterone to values higher than the peak value of the daily rhythm means that the latter is not the maximum possible level for the fowl (Perry, 1973). A comparison should be made with results obtained with hens housed in other conditions before it can be concluded with certainty that egg laying has an influence on corticosterone levels in the blood.

We thank Miss Annemarie Vonk and Mr F. van Lammeren for their excellent technical assistance. 


\section{References}

Beuving, G. (1976) A study of plasma corticosterone levels in laying hens. Proc. Vth Eur. Poult. Conf., Malta Vol. II, 1042-1049.

BoIssin, J. \& AsSENMAChER, I. (1968) Rythmes circadiens des taux sanguin et surrénalien de la corticostérone chez la Caille. C.r.hebd.Séanc. Acad.Sci., Paris 267, 2193-2196.

Boissin, J. \& AssenmaCHER, I. (1970) Circadian rhythms in adrenal cortical activity in the quail. J. Interdiscipl. Cycle Res. 1, 251-265.

BRowN, K.I. (1967) Environmentally imposed stress. In Environmental Control in Poultry Production, pp. 101-113. Ed. T. C. Carter. Oliver \& Boyd, Edinburgh.

Buckland, R.B. \& Blagrave, K. (1973) Effect of feeding chlorpromazine, metyrapone and pargyline to chicks on plasma corticoid levels and the effect of stress on their relationship to body weight. Poultry Sci. 52, 1215-1217.

Culbert, J. \& Wells, J.W. (1975) Aspects of adrenal function in the domestic fowl. J. Endocr. 65, 363-376.

DE JONG, F.H. \& VAN DER MOLEN, H.J. (1972) Determination of dehydroepiandrosterone and dehydroepiandrosterone sulphate in human plasma using electron capture detection of 4-androstene-3,6,17trione after gas-liquid chromatography. $J$. Endocr. $53,461-474$.

FrANKel, A.I. (1970) A neurohumoral control of the avian adrenal: a review. Poultry Sci. 49, 869-921.

FURR, B.J.A. (1973) Radioimmunoassay of progesterone in peripheral plasma of the domestic fowl in various physiological states and in follicular venous plasma. Acta endocr., Copenh. 72, 89-100.

FurR, B.J.A., BONNEY, R.C., ENGLAND, J. \& CUNNINGHAM, F.J. (1973) Luteinizing hormone and progesterone in peripheral blood during the ovulatory cycle of the hen, Gallus domesticus. J. Endocr. 57, 159-169.

JoSEPh, M.M. \& MEYER, A.H. (1973) Daily rhythms of plasma corticosterone in the common pigeon, Columba livia. Gen. comp. Endocr. 20, 326-330.

Kappaut, B. \& Van Tienhoven, A. (1972) Progesterone concentrations in peripheral plasma of laying hens in relation to the time of ovulation. Endocrinology 90, $1350-1355$.

MARTIN, G. (1975) Ueber Verhaltensstörungen von Legehennen im Käfig. Ein Beitrag zur Klärung des Problems tierschutzgerechte Hühnerhaltung. Angew. Ornithol. 4, 145-176.

MuRPHY, B.E.P. (1967) Some studies of the proteinbinding of steroids and their application to the routine micro and ultramicro measurements of various steroids in body fiuids by competitive protein-binding radioassay. J. clin. Endocr. Metab. 27, 973-990.

MURPHY, B.E.P. (1971) Hormone assay using binding proteins in blood. In Principles of Competitive Protein-Binding Assays, pp. 108-127. Eds W. D. Odell \& W. H. Daughaday. J. B. Lippincott Company, Philadelphia.

Perry, G. (1973) Can the physiologist measure stress? New Scientist, 18th October, 175-177.

STURKIE, P.D. (1976) Heart and circulation, anatomy, hemodynamics, blood pressure, blood flow and body fluids. In Avian Physiology, 2nd edn, pp. 76-101. Ed. P. D. Sturkie. Springer Verlag, New York.

WeIss, J. \& BRAND, J.H. (1974) Untersuchungen über die NNR-Funktion bei landwirtschaftlichen Nutztieren mit Hilfe der Cortisol- und Corticosteronbestimmung nach dem Prinzip der konkurrierenden Eiweissbindungsanalyse. Zentbl. Vet. Med. A 21, 225-242. 